\title{
AUTHOR CORRECTION \\ Correction to: What Is Frailty? Perspectives from Chinese Clinicians and Older Immigrants in New Zealand
}

\section{Gary Cheung ${ }^{1} \cdot$ Susan Gee ${ }^{2} \cdot$ Hamish A. Jamieson ${ }^{2} \cdot$ Hans Ulrich Bergler ${ }^{3}$}

Published online: 23 April 2021

(c) The Author(s) 2021

\section{Correction to: Journal of Cross-Cultural Gerontology https://doi.org/10.1007/s10823-021-09424-0}

Correction is needed to the names of the 3rd author and 4th author in the original publication. The correct author names are presented in this Erratum.

Open Access This article is licensed under a Creative Commons Attribution 4.0 International License, which permits use, sharing, adaptation, distribution and reproduction in any medium or format, as long as you give appropriate credit to the original author(s) and the source, provide a link to the Creative Commons licence, and indicate if changes were made. The images or other third party material in this article are included in the article's Creative Commons licence, unless indicated otherwise in a credit line to the material. If material is not included in the article's Creative Commons licence and your intended use is not permitted by statutory regulation or exceeds the permitted use, you will need to obtain permission directly from the copyright holder. To view a copy of this licence, visit http://creativecommons.org/licen ses/by/4.0/.

Publisher's Note Springer Nature remains neutral with regard to jurisdictional claims in published maps and institutional affiliations.

The online version of the original article can be found at https://doi.org/10.1007/s10823-021-09424-0

Gary Cheung

g.cheung@auckland.ac.nz

1 Department of Psychological Medicine, The University of Auckland, Private Bag 92019, Auckland Mail Centre, Auckland 1142, New Zealand

2 University of Otago and Canterbury District Health Board, Christchurch, New Zealand

3 University of Otago, Christchurch, New Zealand 